Education and Post-Communist Transitional Justice: Negotiating the Communist Past in a Memorial Museum

Duncan Light ${ }^{1}$, Remus Creţan ${ }^{2}$ \& Andreea-Mihaela Dunca ${ }^{3 *}$

1 Faculty of Management

Bournemouth University

Fern Barrow

Poole

Dorset

UK

BH12 5BB

dlight@bournemouth.ac.uk

2 Department of Geography

Universitatea de Vest din Timişoara

Bd Vasile Pârvan nr 4

Timişoara 300233

Romania

cretan.remus@gmail.com

3 Department of Geography

Universitatea de Vest din Timişoara

Bd Vasile Pârvan nr 4

Timişoara 300233

Romania

andreea.dunca@e-uvt.ro

Corresponding author: Remus Creţan

*All authors contributed equally to preparing this paper 


\title{
Education and Post-Communist Transitional Justice: Negotiating the Communist Past in a Memorial Museum
}

\begin{abstract}
This paper examines the role of education within post-communist transitional justice. It focuses on the ways in which young Romanians negotiate the communist past during an educational visit to a memorial museum. The museum enabled these visitors to better understand the repression of the communist era, had limited impact in changing their attitudes towards communism, but it did provoke reflection upon and comparison between the present and the communist past. Visitors recognized the role of the museum as a site of memory within post-communist transitional justice, but were also critically aware of the limitations to what the museum could achieve. The implications of these findings for post-communist transitional justice are examined.
\end{abstract}

\section{Keywords:}

Transitional Justice, education, memorial museum, youth, Romania 


\section{Introduction}

The post-communist states of Central and Eastern Europe and the former Soviet Union have, to various degrees, engaged in transitional justice projects intended to reckon with their authoritarian pasts (Stan 2013a). Such projects have focused on trials of former communist officials, lustration, public access to security service files, property restitution, history commissions, and memorialisation projects, particularly for the victims of repression (Stan 2013a; 2013b; Nedelsky and Stan 2015; Ciobanu 2015). Another important (but often overlooked) component of transitional justice is education. In particular, educational initiatives are a means to ensure that reconciliation and rebuilding projects are not confined to political elites but also impact the everyday lives of the wider citizenry (Cole 2007a). Education in schools and universities is underpinned by the potential role of young people as agents of change who can, as they grow up, consolidate values such as respect for human rights and democracy (Jones 2012, 2016; Davies 2017; Ladisch 2018). Children and young people are, therefore, key stakeholders in transitional justice projects (Cole 2017; Ladisch 2018) and the potentially transformative role of education is not something which transitional justice actors can ignore (Cole and Murphy 2009; Cole 2017).

This paper focuses on education in the specific context of a memorial museum. Such museums are a common element of transitional justice projects (and there are many examples in the post-communist world) that aim at presenting and interpreting - particularly for young people - past episodes of conflict, repression or human rights abuses, thereby educating the next generations by explaining what happened in the past (Hamber 2012; Sodaro 2018). While the role and importance of memorial museums is widely recognized, the impact of visits to such places - and their broader contribution to transitional justice - is underresearched and poorly-understood (Duggan 2012; Hamber, Ševćenko, and Naidu 2010). As such, the ways in which memorial museums enable their educational visitors to better understand a repressive past requires fuller investigation.

This study therefore aims to advance knowledge about the role of memorial museums within post-communist transitional justice. In particular, we focus on a museum in Romania which seeks to educate both Romanians and foreign visitors about the hardship and repression of the communist regime (1947-1989). Many young Romanians make educational visits to the museum and we focus on one such group with no direct experience of the communist era. The aims of this study are twofold: 1 ) to examine the ways in which these visitors responded 
to the museum's presentation of the communist past, including both their attitudes to the communist regime and reflection on the post-communist present; and 2) to explore their views about the role, possibilities, and limits of that museum within transitional justice in Romania. We argue that educational visits to a memorial museum can allow young people to encounter the traumas of the communist regime and negotiate broader processes of postcommunist transitional justice. However, such sites may be less effective in changing attitudes towards the communist past than is sometimes hoped for. While the findings of this study are particular to Romania, they have broader relevance to other post-communist settings (including states in Central and Eastern Europe and the former Soviet Union) which are currently engaged in post-communist transitional justice.

\section{Transitional Justice, Education and Memorial Museums}

Educational initiatives are central to transitional justice. In particular, teaching in schools and universities can directly address past conflicts, repression or human rights abuses (Cole 2007b, 2017; Ramírez-Barat and Duthie 2015). By introducing a 'pedagogy of truth and justice into the classroom' (Ciobanu 2008, 58) education can contribute to the acknowledgement of harm and suffering, truth-telling, the recognition of victims, and a move towards reconciliation; these, in turn, can strengthen a democratic culture and respect for human rights (Cole 2007a; Hamber, Ševćenko, and Naidu 2010). As Salomon (2004, 258) argues in the specific context of peace education, the basic aims are 'changed attitudes, increased tolerance, reduced prejudices and weakened stereotypes'. Encouraging young people to engage in critical reflection about the past can strengthen their understanding of human rights (Hamber, Ševćenko, and Naidu 2010). In this context, education can reinforce the message of 'never again' which underpins other measures of transitional justice.

If formal education is to contribute to reconciliation and respect for human rights among young people, reform and depolicitization of the education system are necessary (RamírezBarat and Duthie 2015). This is usually achieved through the introduction of new curricula (Davies 2017) which, in turn, requires the production of new school/university textbooks, particularly for the teaching of history (Cole 2007b; Cole and Murphy 2009). However, this can be a challenging project, given the conservative nature of history education and its widespread use in building group cohesion and allegiance to the nation-state (Cole 2007b). Furthermore, a new (history) curriculum may not, in itself, be sufficient to bring about 
reconciliation or respect for human rights. Teachers may be resistant to change (Duggan 2012) and in extreme cases schools can sustain - rather than challenge - existing injustices (Cole 2007b). Therefore, of equal importance is broader pedagogical reform, particularly how teachers are trained and how they teach (Cole and Murphy 2009; Davies 2017). In other words, reforming how teachers teach is as important as what is taught (Cole 2017).

In post-communist Central and Eastern Europe education reform has been a priority. All former communist states introduced legislation to reform (to varying extents) the education system (Daun and Sapatoru 2002). Such reform centred on the depoliticization of education and the end of centralized state control; the removal of the state's monopoly over education; and decentralisation of the management of education (Cerych 1997). In a context in which transitional justice in Central and Eastern Europe has placed particular emphasis on reckoning with the communist past (Gledhill 2011; Stan 2013a; Rusu 2017) educational reform has prioritized reforming the teaching of history. On one hand, there has been a drive to correct the distorted narratives of communist-era historiography. This has required new history textbooks for use in schools (Stan 2013b; see also Cole 2007b) whilst also allowing teachers a choice of textbooks for classroom use. On the other hand, there has been a concern to educate young people about the repression and human rights abuses of communist regimes in order to contribute to strengthening post-communist democracies (Ciobanu 2008). The extent to which these two strategies have been embraced varies considerably in postcommunist states, depending on the broader political commitment to transitional justice and on political approaches to managing the communist past.

Education within transitional justice projects is not confined to schools or universities. It also can be more informal in nature, in the form of visits to sites of memory such as memorials, museums and other commemorative places (Cole 2017). Memorialisation, like education, has been central to transitional justice in post-communist Central and Eastern Europe (Light and Young 2015; Zombory 2017). Memorials and museums have a pedagogical function which can underline the message of 'never again' for future generations (Moore 2009; Sodaro 2018); keep alive the memories of past human rights abuses; present stories that have previously been silenced; and reaffirm collective identities rooted in a traumatic past (Jelin 2007). Museums in particular have become key sites for representing and remembering human rights abuses (Dean 2013), so that the establishment of memorial museums is commonplace in societies exiting from conflict or authoritarian rule. They are also sometimes 
established as a form of 'outreach' by national or international human rights courts and tribunals (Cole 2017).

Memorial museums aim to provide powerful sensations for their visitors and to impress upon them the repression and injustices associated with past events. Their approach is analogous to the 'pedagogy of discomfort' which is utilized in more formal educational settings to push learners beyond their 'comfort zones' (Zembylas and McGlynn 2012, 41). This is achieved in two ways. First, many memorial museums are housed in buildings that were part of the apparatus of repression of the former regime (Jelin 2007; Zombory 2017). These include prisons, detention centres, interrogation units, and the former headquarters of the security services. In this way, visitors get a unique and visceral experience of being inside a building that is directly associated with suffering and state-sponsored violence (Hamber, Ševćenko, and Naidu 2010). Second, memorial museums use presentation strategies intended to encourage visitors to develop empathy and identification with victims of violence. These include photographs of victims, collections of their personal items, and audio/visual testimonies of those who experienced violence (Zombory 2017; Sodaro 2018). Memorial museums frequently use state-of-the-art interactive displays intended to draw the visitor into the story: as such, the stories they tell are of more importance than the objects they display (Sodaro 2018). The intent is that visitors will leave with a fuller commitment to social justice and a concern to prevent the repetition of past political violence (Hamber 2012; Sodaro 2018).

Memorial museums attract two principal groups of visitors. The first comprises tourists, both domestic and international, many of whom will seek a degree of informal learning during their visits (Light 1995; Kuo 2017). The second group comprises school pupils and university students who visit as part of formal educational study of the recent past. Indeed, educational visits by children and young people are central to the mission of many memorial museums. Consequently, school/university groups frequently make up a significant proportion (and sometimes a majority) of visitors to such sites (Cole 2017; Dobre 2013; Flynn and King 2007; Hamber, Ševćenko, and Naidu 2010; Wight 2016). The informal learning setting of a museum creates possibilities for young people to engage with the recent past in a way that is different from their usual learning environments. Underpinning such visits is the notion of experiential learning (Behrendt and Franklin 2014; Stone and Petrick 2013) in which the excursion is the starting point for reflection, thought and action (Kolb 2015). For young 
people, leaving the classroom or lecture theatre facilitates a form of learning - 'authentic, first-hand and sensory-based' (Behrendt and Franklin 2014, 237) - which cannot be replicated in a formal educational setting. Furthermore, during a museum visit young people have greater freedom to discuss, debate, negotiate and even contest the issues with which they are presented, drawing on both their formal learning about the recent past and narratives that they have encountered from other sources (such as their families). This creates possibilities for more nuanced forms of learning. It also implies that a visit to a museum or memorial site is not a one-way transmission of knowledge from the museum to the student. Instead, it has the potential to be a more dynamic encounter in which, rather than being passive learners, young people are able to actively engage with the material presented to them (Dean 2013). As such, educational visits to memorial sites have the potential to create transformative learning experiences among participants (McGladdery and Lubbe 2017) that are central to the role of education in transitional justice.

For all the importance attached to memorial museums, their contribution to transitional justice tends to be assumed rather than subject to empirical scrutiny (Hamber, Ševćenko, and Naidu 2010). In particular, little is understood about the ways in which school and university groups engage with the messages they encounter in such museums. Similarly, the ways in which memorial museums educate their visitors and contribute to reconciliation with a problematic past is poorly understood and rarely subject to systematic investigation (Duggan 2012). There is some evidence that visits to memorial museums can bring about learning and contribute to changes in attitudes (see Bickford 2009; Hamber, Ševćenko, and Naidu 2010; Hamber 2012). These are essentially short-term processes and the longer-term impact is less certain (Hamber 2012). A further issue is that most analyses of memorial museums focus on the period immediately after they are opened and little is known of how visitors experience the site over longer time periods (Hamber, Ševćenko, and Naidu 2010).

\section{Materials and Method}

This paper contributes to knowledge by focusing on the experiences of a group of educational visitors to a memorial museum which interprets the repression of communist rule in Romania. Our aim was to explore the ways in which young people encounter the communist past and to consider the broader implications for transitional justice, particularly the process of coming to terms with an authoritarian past. The findings of this study apply to a particular group of young people and we do not seek to make broader generalisations about how young 
Romanians respond to the communist past. Although this was an educational visit our focus extended beyond simply investigating new knowledge gained or evaluating whether the museum is a 'success' in educational terms. Instead, we take a broader perspective which focuses on the ways in which the students interacted with the museum's messages and reflected on its role within post-communist transitional justice in Romania. In particular, we examine four issues: 1) the ways in which the students negotiated the museum's presentation of communism (and reconciled it with their own prior understandings of the communist past); 2) their views about the importance of the museum as a medium of remembrance of the hardships of communist rule; 3 ) the ways in which the visit had caused them to reflect upon the differences between the communist past and the post-communist present; and 4) their opinions about the museum's contribution to transitional justice in Romania.

\section{Sighet Memorial Museum}

This analysis adopts a case study approach using a single memorial museum: Sighet Memorial Museum (hereafter 'the Museum'), located in the town of Sighetu Marmatiei in northern Romania (see Figure 1). The case selection is justified on the following grounds. First, Sighet Museum (founded in 1993) was one of the first institutions in post-communist Central and East Europe to focus specifically on communist repression (Zombory 2017). As one of the best-known and longest-established museums addressing the communist era it is an appropriate site through which to explore the nature of educational visits within postcommunist transitional justice. Second, although a growing number of museums in Romania focus on the communist era, Sighet Museum is the largest, most visited, and most reputed. Third, while there has been extensive academic analysis and commentary about the Museum (Ciobanu 2008; Cristea and Radu-Bucurenci 2007; Dobre 2013; Haliliuc 2013; Ploscariu 2013; Pohrib 2016; Zombory 2017) this body of research has almost universally treated the Museum as a 'text' to be critically interpreted but has rarely considered (or engaged with) the perspectives of the people who actually visit it. The article moves the debate forward by directly focusing on the experiences of young people who visit the museum.

FIGURE 1 HERE. Title: Location Map

Sighet Museum was founded at a time when there was little desire in Romania to confront the abuses of the recent past. As Rusu (2017) argues, there are two basic strategies for managing a difficult past: forgetting (deliberate 'amnesia') and remembering (confronting the recent 
past). Since much of Romania's post-communist ruling elite had deep roots in the Communist Party there was little interest in addressing the repression and abuses of the communist era (Stan 2013a, Rusu 2017). Similarly, there was a reluctance to embrace transitional justice (Gussi 2017) and many measures were not adopted until 2000. At the same time, many ordinary citizens had little interest in remembering the trauma and hardships of the communist era (particularly in a context of increasing household economic austerity). As a result a deliberate strategy of forgetting the communist past took priority over remembering.

Consequently, non-governmental organisations led in seeking accountability for the abuses of the communist regime (Stan 2013b). One such group - the Civic Academy Foundation - was particularly active in memorialising the communist past. In 1993 it purchased a building which had been used as a prison by the communist regime in the late 1940s and the 1950s. Much of Romania's pre-war political elite was incarcerated in the prison (and over 50 people died there). The Foundation converted the building into a museum which opened to visitors in 1997. It is part of a broader memorial complex entitled 'Memorial to the Victims of Communism and to the Resistance'. The museum has progressively expanded since opening and now features presentations in more than 50 rooms (including many former prison cells). The displays focus on the nature of life in the prison; broader communist-era repression and its victims; and the anti-communist resistance in the late 1940s and the 1950s. The museum is underpinned by the epithet 'memory as a form of justice' and is intended to educate both Romanians and foreign visitors about communist-era repression. It does not seek to present a balanced account of Romanian communism but instead unequivocally condemns communism as a criminal system (Dobre 2013; Ploscariu 2013). When it opened the museum was one of the few institutions in Romania to adopt this stance: subsequently it has become wider state policy through the 2006 Presidential Commission which explicitly condemned and criminalized the communist regime (Rusu 2017). In 2017 the museum attracted 106,649 visitors. Educational groups (schools and universities) make up a substantial proportion (46\%) of these visitors ${ }^{1}$ and are one of the Museum's key target groups. The Museum also hosts a summer school for pupils aged 14-18.

\section{Data Collection and Analysis}

Focus groups were used for data collection. They allow investigation of a topic in depth with an emphasis on group rather than individual responses (Bryman 2016; Morgan 1997). Focus groups enable participants to explore and negotiate different perspectives about a topic 
(Cameron 2005) thereby engaging with the plurality of viewpoints that participants may hold (Crang and Cook 2007). They also have the advantage of allowing more rapid data collection than would be the case with individual interviews.

The participants in the focus groups were all final year students at Universitatea de Vest din Timişoara (University of the West in Timişoara), located some $400 \mathrm{~km}$ from the Museum. All 45 participants on the field visit were invited to join the focus groups and 43 chose to do so. All were aged between 20 and 23 (meaning that they were born after the collapse of the communist regime in December 1989). Fifteen of the participants were male and 28 were female, and only four had visited the museum previously. All were from the western part of Romania (predominantly Banat and western Transylvania). Most investigations into the impacts of visits to memorial museums involve data collection soon after the end of the visit and therefore focus on short-term experiences and learning (Hamber, Ševćenko, and Naidu 2010). However, we sought to explore the impact of the visit over a longer time scale to allow for a period of reflection which is central to experiential learning (Behrendt and Franklin 2014; Kolb 2015). For this reason the focus groups were undertaken at the end of the university's teaching term in December 2017 (meaning that there was an interval of two months between the visit and data collection). We recognise the possibility that the students may have encountered other sources of information about the communist past in the period between the visit and the focus groups. However, we consider this unlikely since most young Romanians have little interest in the communist era and give it very little thought in their daily lives.

Before each focus group, participants were given an information sheet explaining the research project. Each participant chose a pseudonym by which they would be identified in the project write-up. The focus groups (which ranged in length from 70-95 minutes) were undertaken in a teaching room in the university and were facilitated by two of the authors. The groups were based on a schedule of 13 questions (drawn from key issues identified in the review of literature) along with unscripted follow-up questions. The questions related to previous visits to the museum; the reason why the museum was established; knowledge of Romanian communism; perceptions of new learning during the visit; the way they felt during the museum visit; the impact of the museum in changing views about the communist past; differences between the communist period and the present; the lessons of the museum for Romania today; the possibility of a return to authoritarian rule; the contemporary need for the 
museum; the contribution of the museum to healing the traumatic memories of the communist era; its contribution to strengthening democracy in post-communist Romania; and their lasting impression of the museum. The two authors facilitating the focus groups were sensitive to the fact that talking about the communist past might make some students uncomfortable (particularly if talking about traumatic family histories) and were prepared to respond accordingly. In fact, there was no evidence that talking about the communist past caused distress or discomfort to any of the participants.

Four focus groups were conducted which aligns with the optimum number necessary to capture the majority of the themes within the data (Guest, Namey, and McKenna 2017). The groups each involved between 10 and 12 participants which is at the higher end for the 'ideal' number of participants (Liamputtong 2011). The availability of rooms meant that it was not possible to schedule more than four groups.

The sessions were recorded with the consent of the participants. The audio recordings were transcribed (in Romanian) and the transcripts then analysed. A form of thematic analysis (Bryman 2016) was employed. It began with repeated close reading of the transcripts, followed by open coding (the identification of initial patterns and recurring ideas in the data). These open codes were subsequently reviewed and grouped into higher-order themes (each of which was given a title) and appropriate sub-themes. To ensure inter-coder reliability this analysis was undertaken independently by each of the three authors. Once all researchers had completed the analysis they compared and evaluated the themes that they had produced. After a process of discussion and negotiation a final set of 6 themes was agreed upon: these captured most of the perspectives in the data; were appropriate to the aim of the research project; and were linked to key issues identified in the review of literature. In order to focus on the research aims, only four of the themes are reported here: knowledge and feelings about the communist past; the need for the museum; appreciation of the present; and the limitations to what the museum can achieve.

\section{The Encounter with the Museum}

\section{Attitudes towards the Communist Past and the Impact of the Museum}

Students visited the museum with a diverse range of background knowledge about Romanian communism. While a few considered themselves well informed, most claimed only limited knowledge. Significantly, the efforts of political elites in the 1990s to bury the communist 
past appear to have succeeded, at least among this particular group of young people (see Rusu 2017). Students' understanding of the communist era came from two principal sources: family and schooling (Creţan et al 2018). Almost two-thirds reported that their parents or grandparents were their main source of information about the communist period. For example, Lola stated: 'Most of what I know was from my family, because I stayed with my grandmother and she always told me about the communist period'. However, the nature of family stories about communism varied widely, often depending upon individual family backgrounds and the place of residence within Romania. In some cases, a student's family had benefitted from the communist system. For example, some had parents or grandparents who were members of the Communist Party, or who had held senior positions within the local state hierarchy. Conversely, other students had negative family experiences which included repression, austerity, or forced internal deportation. In some instances, students reported that they had spoken little (and in a few cases, not at all) with their parents about the communist era so that their parents were not important as a source of information.

Learning at school was equally inconsistent. Only 21 of the students had studied Romanian communism at school and only eight of them described their schooling as their main source of information about the communist era. It was also apparent that parents and school were sources for understanding very different aspects of communism. School learning tended to focus on the broader political dimensions of communism, along with key leaders and dates. Conversely, parents and grandparents were the principal source of information about everyday life. As Tedi stated: 'at school I learnt more about the economic and ideological aspects of communism, more than the social aspects; those I found out from my family'. As such, students learnt different histories of Romanian communism from family and school and had to reconcile these different accounts themselves.

These findings reflect the wider ambivalence about the communist past in post-communist Romania (see Stan 2013a). In some cases the desire to forget meant that parents had apparently not discussed the recent past with their children. Furthermore, during the 2000s, many schools had shown little interest in teaching Romanian communism so that some of the focus group members had not had the opportunity to learn about this period during their schooling. While the education system was restructured in the 1990s (Stan 2013a) many school textbooks in use made no reference to the communist era (Rusu 2017). When a later generation of history textbooks was adopted in the late 1990s many devoted little space to the 
communist period. Furthermore, teaching the history of the communist period was not obligatory for schools (Stan 2013a). Thus, while school education is frequently identified as having a decisive role to play within transitional justice (Cole 2007a, 2007b, 2017) this role is weakened if there is a lack of desire among both policy makers and teachers to address a problematic past.

Students were asked about their perceptions of the communist period and it was clear that they had mixed views. Fewer than half viewed the communist period in negative terms. For example, Vova stated 'it was bad due to the restrictions on freedom of movement and expression'. However, an equal number were more ambivalent and could identify both good and bad aspects of communism. One example was Andu: 'I think of the communist period in both a negative and a positive way; I have divided feelings because there were good things and bad things'. Didi made a similar point:

'It depends on which aspects. In negative terms...they didn't have freedom of expression, food, electric power, basic necessities; and in positive terms because after you finished university you had a job and we can’t neglect the achievements of the communist period...the infrastructure that was built'.

Furthermore, a few students regarded the communist era in predominantly positive terms, particularly when juxtaposed against the uncertainties of the post-communist era. Iris stated that 'compared with the period in which I live I consider it [the communist era] positive'.

These views are not exceptional: many surveys have indicated widespread favourable views of the communist era in Romania, both among the population in general and among young people in particular (see Tileagă 2012; Stan 2013a; Rusu 2017). Many students spoke of hearing their parents (and grandparents) speaking in positive terms about life under communism. Such attitudes are usually attributed to nostalgia among older people (which is commonplace elsewhere in the post-communist world) (Todorova and Gille 2010). In most cases nostalgia does not indicate a desire to return to communist rule, but is an expression of loss for the certainties of communism (such as guaranteed jobs) and of the significance of the communist era for personal biographies (Stan 2013a). As such, efforts by elite actors (such as the Civic Academy Foundation) to condemn the communist past collide with personal memories and narratives among the wider population (Tileagă 2012). Nevertheless, since 
such nostalgia is grounded in a desire for a fairer society, it does not compromise transitional justice and democratic consolidation (Petrescu 2017).

With its focus on the repression and the incarceration of opponents, the Museum had presented the students with an aspect of the communist past of which most were unaware (since they had not heard about it from their parents or schooling). Consequently, two-thirds of the students considered that they had learnt something new about the recent past. For example, Bebe stated: 'I didn't believe that communism in Romania manifested itself with such barbarity'. Similarly, Cara reflected 'I didn't know that there were so many victims of communism...I didn't even have a vague idea about how many there could be and I realise that there were many'. For others the museum had deepened their existing knowledge: Roza stated 'I've understood things in much more depth. It's one thing to hear about concentration camps and another to see with your own eyes how people were detained'.

While the Museum had confronted the students with an aspect of the recent past about which they knew little, its impact on their perceptions of the communist regime was unclear. Students were asked if their view of the communist era had changed as a result of their visit (see Table 1). The majority of students did not change their opinion (whether it was negative or ambivalent). Some stated that the visit had reinforced their existing opinions. For example: 'I haven't changed my opinion about the communist period; only that my negative feeling about that period has further increased' (Bebe). Only seven students said that the museum had changed their views so that they felt more negative about the communist era. Amir stated:

'from good to bad, I could say. It was said that the communist period was better and many positive aspects have been spoken about. Seeing what happened at the Memorial and in the cells I understood that it was much more negative... everything was done with bestiality and cruelty’ 
Table 1: Opinions about the communist period, before and after the visit

\begin{tabular}{|l|c|c|c|c|c|}
\hline \multirow{2}{*}{} & \multicolumn{5}{|c|}{ Initial opinion of communist period } \\
\cline { 2 - 6 } $\begin{array}{l}\text { Opinion after the } \\
\text { visit }\end{array}$ & $\begin{array}{c}\text { Negative } \\
\text { opinion }\end{array}$ & $\begin{array}{c}\text { Mixed } \\
\text { opinion }\end{array}$ & $\begin{array}{c}\text { Positive } \\
\text { opinion }\end{array}$ & $\begin{array}{c}\text { No } \\
\text { response }\end{array}$ & Total \\
\hline Unchanged & 12 & 12 & 1 & 2 & 27 \\
\hline $\begin{array}{l}\text { Reinforced/ } \\
\text { underlined existing } \\
\text { view }\end{array}$ & 5 & 2 & 1 & 1 & 9 \\
\hline $\begin{array}{l}\text { More negative } \\
\text { opinion about } \\
\text { communism }\end{array}$ & 2 & 5 & 0 & 0 & 7 \\
\hline & 19 & 19 & 2 & 3 & 43 \\
\hline
\end{tabular}

This raises the question of why the museum did not appear to succeed in changing attitudes towards communism among most of these students. There was no evidence in the focus groups that students were resisting the Museum's condemnation of communism, but they had to reconcile what they encountered there with the more positive reports they had received from parents and grandparents. Whilst they recognized the repression and hardship of communist rule, most students were not persuaded by the Museum to think about communism in wholly negative terms. It was apparent that these students were not uncritically accepting the Museum's message but instead they were 'co-authoring meaning' (Trofenenko 2011), mediating the messages they encountered with what they had learned from other sources (Jones 2012). This suggests that memorial museums may not necessarily change the way that visitors feel about the recent past, although they can add depth and nuance to understanding that past. This, in turn, implies that educational visits to memorial museums may have a more limited contribution to healing and reconciliation than is sometimes claimed (see Hamber 2012). However, these findings apply only to university students who may be better able to critically reflect on what they encounter. Other visitor groups (such as pre-university groups or adult Romanians) might respond to the Museum's message in a different way. 


\section{Reflecting on the Present}

The encounter with the museum was not only about the communist past. Instead, the visit had also stimulated students to reflect upon the post-communist present. Students repeatedly highlighted the advantages they enjoyed which were not possible under communist rule. Mara, for example, stated 'for me it made me grateful for the time in which I live, that we have peace and that I didn't live through communism'. Zara stated 'I think that now we have freedom which we didn't have in the communist period and [today] it's much better than it was then'. Sisi was more direct: 'God! In these times we are free and how good it is to be free compared to that period'.

One particular liberty - freedom of expression - was frequently mentioned. Luci's response was typical: 'It's much better than then. It's a free country and everybody has the right to express themselves freely'. Amir went into greater detail: 'you can say what you want; you can criticize the party leaders, you can express your discontent with parliament...and it's not a problem that if you say something about X or Y you'll end up in prison'. Other students construed the difference between the communist past and the present in terms of the human rights they now enjoyed. Zoia stated 'at present in truth we have a series of citizens' rights and freedoms which are respected', while for Manu 'an advantage [of the present] would be that we have many more rights than in that period'.

These findings illustrate how a visit to the museum had enabled many students to make a connection between the past and the present. Indeed, memorialisation within transitional justice is not only about remembering, but also about using what is remembered to provoke a critical engagement with the present (Moore 2009; Hamber 2012). In this sense, memorial museums are both backward and forward-looking: they are about the past but they operate in the present (Dean 2013). By emphasising the hardships of the communist past, Sighet Museum had highlighted the distance from that past, alerting students to how the present is different. For this reason, many of them (including those with mixed views about the communist period) spoke of being thankful for the present that they now lived in.

While the museum visit had underlined the advantages of the present, some students also identified the ways in which the communist past continues to influence the present (see Zombory 2017). Many students had limited knowledge of Romanian communism but were 
well aware that their country had not made a clear break with the communist past. For example, Cara highlighted the political elite: 'a big part of the political class of today is the political class from then who grew up in the communist period'. In a similar way, Bebe highlighted the persistence of communist-era ways of thinking, arguing that 'Romania today resembles Romania yesterday...It's the same disastrous political system, the same thinking, even if we are in a democratic period'. Other students alluded to broader continuity with the communist era. For example, Dodo stated:

'We're still somehow tied to the communist period. We still allow what remains from communism to dominate...We haven't escaped from corrupt politicians and I think in a way this is a negative factor which I hadn't acknowledged about the communist period but which is now coming to light'.

Mara made a similar point:

'We're still tied to our tragic past and I think that this can best be seen in the leadership of the country today, who still do the same things that they did in the past... I think we're in a transition period'.

Among politicians the concept of a 'transition period' was dominant in the 1990s but virtually disappeared in the 2000s, particularly as Romania's accession to the European Union in 2007 was seen as the end of the reform process. Here Mara recognizes that the 'transition' from communism is a longer-lasting process, so that the communist era continues to shape Romania's post-communist evolution.

\section{The Role of the Museum}

Students clearly understood the importance of Sighet Museum as a site of remembering in post-communist Romania. Remembrance of past abuses is a key aspect of transitional justice (Jelin 2007; Sodaro 2018; Stan 2013a) that is intended to provide reparation for those who suffered (Cole 2017). Tete identified the role of the museum as being 'to remember the communist period and everything that...those who suffered in the communist period went through'. Others identified the importance of the museum in maintaining the memory of those individuals who had opposed the communist regime. For example, Mara contended that the museum was established 'to commemorate those who fought against communism', while 
Lola stated 'at least their memory is still alive, through this we remember them, all those who fought'. Thus, remembering is recognized as a moral obligation on the part of those who did not experience communist repression (Sodaro 2018), ensuring that those who suffered under communism receive due acknowledgment and recognition.

Furthermore, many students recognized the role of remembrance in ensuring that the repression and human rights abuses of the communist dictatorship were never repeated. This connects to the broader issue of 'never again', a tenet of both memorialisation and education in the context of transitional justice (Cole 2007b, 2017; Hamber 2012; Moore 2009). The issue of 'never again' was not specifically raised in any of the questions but, unprompted, 16 students highlighted the issue. For example, Zoia stated 'I think that the museum has a role in commemorating the victims and was done so that we don't repeat the mistakes of the past and that is the lesson for Romania: to learn from mistakes and to not repeat them'. Several students evoked (although probably without knowing the exact source) George Santayana's famous maxim: 'Those who cannot remember the past are condemned to repeat it' (1905). Tete stated 'How does that quote go? "Whoever forgets history will repeat it". So we must remember those events in order to not repeat the same mistakes'. These young people understood that remembrance is as much about the present as about the past: in order to avoid the non-repetition of communist rule it is necessary to keep the memory of communism alive in post-communist Romania.

Furthermore, students recognized that remembering the communist past was, by necessity, a long-term project. When asked if, almost 30 years after the fall of communism, there was still a need for Sighet Memorial Museum the students were unanimous that the museum continued to be relevant. Some stressed the importance of the Museum as an ongoing commemoration of the victims of communist repression. Rubi argued that Sighet Museum is 'a sign of appreciation for those who suffered in that period and so that people from future generations will better know the details of how they lived then'. Similarly Gigi contended that 'it [the Museum] should always exist in my opinion, out of respect for those who suffered there'. Others identified the importance of the museum as an educational resource for those (including their own generation) who had not directly experienced communism. For Zara, the museum 'helps the present-day Romanians who have not gone through the communist period to appreciate what they have now', while Jana claimed that 'there is a need for future generations to realise what their, and our, ancestors went through'. These students 
understood that the obligation to remember the communist era is an ongoing process: as such they were acknowledging the long-term role of the museum as an educational resource for young people. Such a stance represents a rejection of the approach among both political elites and ordinary citizens in the 1990s which emphasized burying and forgetting the communist past.

Some students highlighted the importance of the Museum in enabling visitors to see (and experience) for themselves the nature of a communist prison. In this they recognized the role of experiential learning as a means for visitors to deepen their understanding of the communist era. For example, Cara argued:

'I think that it's a very good history lesson for anyone because even if we know certain things related to the communist regime from history at school or if we know them from our family, the fact that you go there and see so many things which happened and [you] read and are informed, then it fills in the picture about the communist regime'.

Similarly, Vivi claimed:

'I think that the generation which now grows up with telephones, tablets and laptops should still see how people lived in that period because at Sighet there aren't only cells; we see a whole way of life'.

Such views underline the value of first-hand experience in the museum over other forms of learning about the communist past (such as family narratives, school textbooks or web sources). The experience of being in the former prison and directly encountering the nature of communist repression can validate, contextualize (or potentially challenge) learning about Romanian communism from other sources.

\section{The Possibilities (and Limits) of the Museum}

While recognising the importance of the Museum for remembering the repression and human rights abuses of the communist era, many of the students were also critically reflective about its broader role within post-communist transitional justice. When asked if the Museum could contribute to the consolidation of democracy, only half of the students agreed. Some argued 
that the most important role of the Museum was in presenting communism as the antithesis of a democratic society. For example, Tete contended that the Museum 'shows us how any type of totalitarian system works... and from this we must learn that democracy is a much better solution for a better future'. Mimi made a similar point, arguing that 'simply the fact that knowing all the negative aspects from that time helps us to avoid them today, to not go back'. However, others were sceptical about the Museum's contribution to transitional justice. Dodo argued bluntly that 'a museum alone can’t strengthen a democratic system', a point echoed by Roza who claimed that 'a museum in a particular part of the country can't make you feel better'. Others pointed out that the museum's location and relatively modest number of visitors meant that its influence was inevitably limited. For example, Tedi contended that 'it's rather isolated and it's not very well promoted in the country and because it's situated in the north of the country it's difficult to reach'.

These responses indicate, once again, how the encounter with the Museum is as much about the present as the past. While they differed on the capacity of the Museum to effect change, these students recognized that what the museum 'does' takes place in the present. Furthermore, Simon (2006, 114) argues that commemorative museums always speak about the future, informing 'competing visions of our present and future civic life'. Since transitional justice is about building a 'different' future, the Museum also implicitly speaks about the form that future might take.

The students were also asked if the museum could heal the painful memories of the recent past - a claim often made for transitional justice (Mégret 2010; Sodaro 2018). Few agreed that the museum could play this role. One stated: 'I'm of the opinion that it can bring relief because it's a homage to those who died there' (Bobi). However, most took the opposite view such as Mira who stated bluntly that 'healing isn't possible', while Bubu contended that healing wasn't the aim of the museum. Other views were more nuanced such as Gina, who argued that the Museum could not heal but 'can only accentuate the pain'. Vega suggested that 'this memorial can't heal painful memories, because you realise that certain people are still suffering because they lost those dear to them in that period and some are maybe still traumatized for this reason'. Others opined that any healing would be very limited such as Tedi, who claimed 'I don't think it can heal the wounds left from the past, but maybe it can bring relief to the relatives of those who were incarcerated there'. 
These users of the museum had clear views about what it could - and could not - achieve in post-communist Romania. As participants in tertiary education they may have been better able to evaluate the broader impact of what they had encountered, and their views may not be representative of other educational visitors. The students recognized that the impacts of a single visit to a memorial museum will be limited (see Hamber 2012). Furthermore, their views about the Museum's contribution to democratisation and healing suggest that the simple existence of a memorial site does not, of itself, mean that it will contribute to broader changes (such as coming to terms with a repressive past) that are central to transitional justice (Hamber, Ševćenko, and Naidu 2010). Indeed, Stan (2013a) argues that the memory projects of civil society actors have made only a limited contribution to strengthening Romania's post-communist democracy. A further issue is the museum's location which constrains its role as an educational resource. As the place where the pre-communist intellectual and political elite were incarcerated, the museum can make strong claims to be an authentic and indeed 'sacralised' space (Zombory 2017, 104). However, the museum's founders have prioritized authenticity of location above accessibility and wider impact. In particular, the museum's location in the far north of the country immediately places limitations on the number of people who will visit, which the focus groups identified as reducing the museum's wider educational impact.

\section{Conclusions}

Education plays a key role within transitional justice, and memorial museums are important resources for enabling citizens to develop a better understanding about past human rights abuses in an informal learning context. This paper has examined the encounter of one group of educational visitors with a memorial museum which interprets Romania's authoritarian past. Students arrived at the museum with existing ideas about the communist period gained from their families and other sources. In most cases the museum had a limited impact in changing the way that students felt about the communist era. Nevertheless, the experience of being in the former prison had enhanced their historical understanding by presenting them with an aspect of the recent past that they had not encountered in the family or school. Students also recognized the role of the museum as a memory site and the importance of remembrance as a way of ensuring that the hardships and suffering of the communist era are not forgotten or repeated. They also understood that such remembrance is a long-term process. Many considered that the museum could make a contribution to the broader transitional justice process of consolidating democracy but they were mostly sceptical about 
its contribution to healing the wounds of the communist era. Overall, it was clear that these visitors had actively and critically engaged with the Museum (see Dean 2013) and as such they were participants and stakeholders, both in the process of remembrance, and in broader processes of transitional justice.

These findings have a broader relevance for post-communist societies engaged in transitional justice. First, educational visits can be an important means for young people to engage with a violent past and participate in the remembrance of that past. Visits to sites of oppression (such as memorial museums) can provide important opportunities for informal experiential learning which can underline the core message of 'never again' and contribute to the broader project of consolidating respect for human rights and a democratic culture. However, such educational visits will be most effective when there is a strong emphasis on confronting the past within formal educational curricula in schools (and universities). Conversely, in cases like Romania - where the education system has been reluctant to address the communist dictatorship (Stan 2013a) - the messages of a memorial site cannot reinforce what is taught in formal education, and indeed may have to compete with other narratives about the recent past derived from families and other sources. This means that the impact of memorial museums intended by their sponsors cannot be taken for granted (see Hamber, Ševćenko, and Naidu 2010) and such museums may have a limited role in shaping perceptions of the recent past.

Second, these findings have relevance for the operators of memorial museums. In particular, they underline the importance for museum professionals of recognising and understanding the broader societal context of remembering and forgetting within which their institutions are situated. It is also necessary to pay attention to the visitors' prior knowledge when designing displays and presentations. This is particularly important if a museum is intended as an educational resource for young people. Furthermore, the proportion of such visitors will increase over time and future generations will increasingly have a diverse range of 'secondhand’ understandings - termed ‘prosthetic memories' by Landsberg (2004) - of past violence. Therefore, interpreting a difficult past in a memorial museum needs to be a dynamic and emerging process, which adapts to changing circumstances, and not a one-off gesture.

A third issue relates to the location of museums and other memorial sites. There are obvious reasons for establishing a museum in a building that was once associated with state repression, including authenticity of location and the moral imperative of providing 
restorative justice for the victims. However, to succeed as transitional justice mechanisms such museums need to be visited. For this, they need to be accessible, that is, they need to be located near major population centres and principal tourist circuits. When this is not the case it constrains the number of educational visitors so that the broader educational impact of the museum will be muted.

A number of directions for future research can be identified. This research has focussed on one type of educational visitors who, as university students, may be better equipped to critically reflect on their experience of visiting the Museum. It cannot be assumed that other educational visitors will respond to the museum in the same way. Since there is a limited understanding of the ways in which young people engage with transitional justice (Cole 2017), the experiences of school groups within memorial museums require further investigation (see Israfilova and Khoo-Lattimore 2018). This issue is of particular importance in societies where conflict or repression is an increasingly distant memory, so that children may have no contemporary frame of reference for understanding traumatic past conflict or repression. As such they may have difficulties distinguishing education for transitional justice from general history education. Key questions for further research include the ways in which such educational visits can change attitudes, promote peace, and develop respect for human rights. A further issue concerns what young people 'do' with the new understandings that they develop in memorial museums and the ways in which these play out in other aspects of their lives. Such practices might include reflecting upon what they have seen, or discussing their encounter with their parents, grandparents or friends.

There is also scope for further research addressing adult visits to memorial museums (and other memorial sites) in societies coming to terms with past conflict or repression. There is a growing body of studies into visitors at such sites but their focus is mostly the perspectives of international visitors. Less is known about domestic visitors: such people may have very different encounters from international tourists, particularly if they have first-hand experience or memories of the violence or repression that is represented. Their visits may be underpinned by a wide range of transitional justice issues including trying to understand what happened, participating in remembrance, honouring victims, and seeking healing. While such practices are frequently claimed for memorial museums they are rarely explored through empirical research. Also significant is that many adults visit memorial museums in the context of domestic (or internal) tourism. To date, the study of transitional justice has paid 
little attention to tourism, but those researching the role of memorial museums within postcommunist transitional justice need to recognise that domestic tourism may be an important mechanism through which citizens engage with a difficult past and which, consequently, merits fuller scrutiny.

\section{Acknowledgements}

We wish to express our thanks to the 43 students who willingly gave up their time to participate in the focus groups. We would also like to thank Adele Ladkin and two anonymous referees for their helpful feedback on earlier versions of this article.

\section{References}

Behrendt, M., and T. Franklin. 2014. A review of research on school fieldtrips and their value in education. International Journal of Environmental and Science Education 9: 235-45.

Bryman, A. 2016. Social research methods, $5^{\text {th }}$ edition. Oxford: Oxford University Press.

Cameron, J. 2005. Focusing on the focus group. In Qualitative research methods in human geography ( $2^{\text {nd }}$ edition), ed. I. Hay, 116-32. Oxford: Oxford University Press.

Cerych, L. 1997. Educational reforms in Central and Eastern Europe: Process and outcomes [1]. European Journal of Education 32: 75-96.

Ciobanu, M. 2008. Teaching history and building a democratic future: Reflections from postcommunist Romania. Democracy and Education 17: 58-62.

Ciobanu, M. 2015. The challenge of competing pasts. In Post-communist transitional justice: Lessons from twenty-five years of experience, ed. L. Stan and N. Nedelsky, 148-66. New York: Cambridge University Press.

Cole, E.A. 2007a. Introduction: Reconciliation and history education. In Teaching the violent past: History education and reconciliation, ed. E.A. Cole, 1-28. Lanham: Rowman and Littlefield.

Cole, E.A. 2007b, Transitional Justice and the Reform of History Education. International Journal of Transitional Justice 1: 115-37.

Cole, E.A., and K. Murphy 2009. Research brief: History education reform, transitional justice and the transformation of identities. New York: International Center for Transitional Justice.

Cole, E.A. 2017. No legacy for transitional justice efforts without education. New York: International Center for Transitional Justice.

Crang, M., and I. Cook 2007. Doing ethnographies. London: Sage. 
Cretan, R., D. Light, S. Richards, and A. Dunca. 2018. Encountering the victims of Romanian communism: Young people and empathy in a memorial museum. Eurasian Geographies and Economics 59: 632-656.

Cristea, G., and S. Radu-Bucurenci 2007. Raising the cross: Exorcising Romania’s communist past in museums, memorials and monuments. In East European representations of communism in cinema and museums after 1989, ed. O. Sarkisova and P. Apor, 276-305. Budapest: Central European University Press.

Daun, H., and D. Sapatoru 2002. Educational reform in Eastern Europe: Shift, innovations and restoration. In Educational restructuring in the context of globalization and national policy, ed. H. Daun, 147-180. London: RoutledgeFalmer.

Davies, L. 2017. The power of a transitional justice approach to education: Post-conflict education reconstruction and transitional justice. New York: International Center for Transitional Justice.

Dean, D. 2013. Museums as sites for historical understanding, peace and social justice: Views from Canada. Peace and Conflict: Journal of Peace Psychology 19: 325-37.

Dobre, C-F. 2013. Teaching communism at the museum: A comparative study of museums dedicated to communism in Eastern and Central Europe. Edukacja Humanistyczna 2: 95106.

Duggan, C. 2012 "Show me your impact”: Evaluating transitional justice in contested spaces. Evaluation and Program Planning 35: 199-205.

Flynn, M.K., and T. King. 2007. Symbolic reparation, heritage and political transition in South Africa’s Eastern Cape. International Journal of Heritage Studies 13: 462-77.

Gledhill, J. 2011. Integrating the past: regional integration and historical reckoning in Central and Eastern Europe. Nationalities Papers 39, 481-506.

Guest, G., E. Namey and K. McKenna. 2017. How many focus groups are enough? Building an evidence base for nonprobability sample sizes. Field Methods 29: 3-22.

Gussi, A. 2017. Paradoxes of delayed transitional justice. In Justice, memory and redress in Romania: New insights, eds. L.Stan and L. Turcescu, 76-98. Newcastle upon Tyne: Cambridge Scholars Publishing.

Haliliuc, A. 2013. Who is a victim of communism? Gender and public memory in the Sighet Museum, Romania. Aspasia, 7: 108-31.

Hamber, B. 2012. Conflict museums, nostalgia, and dreaming of never again. Peace and Conflict: Journal of Peace Psychology 18: 268-81.

Hamber, B., L. Ševćenko, and E. Naidu. 2010. Utopian dreams or practical possibilities? The 
challenges of evaluating the impact of memorialization in societies in transition. International Journal of Transitional Justice 4: 397-420.

Israfilova, F., and C. Khoo-Lattimore. 2018. Sad and violent but I enjoy it: Children’s engagement with dark tourism as an educational tool. Tourism and Hospitality Research, 19: 478-487.

Jelin, E. 2007. Public memorialisation in perspective: Truth, justice and memory of past repression in the southern cone of South America. International Journal of Transitional Justice 1: 138-56.

Jones, B. 2012. Exploring the politics of reconciliation through education reform: The case of Brćko District, Bosnia and Hercegovina. International Journal of Transitional Justice 6: 126-48.

Jones, B. 2016. Educating citizens in Bosnia-Herzegovina - experiences and contradictions in post-war education reform. In Transitional justice and reconciliation: Lessons from the Balkans, eds. M. Fischer and O. Simić, 193-208. Abingdon: Routledge.

Kolb, D.A. 2015. Experiential learning: Experience as the source of learning and Development, $2^{\text {nd }}$ edition. Pearson: New Jersey.

Kuo, I.-L. 2017. Theories of learning and their application in interpretation, In Visitor management in tourism destinations, ed. J.N. Albrecht, 159-69. CABI: Wallingford.

Ladisch, V. 2018. A catalyst for change: Engaging youth in transitional justice. New York: International Center for Transitional Justice.

Landsberg, A. 2004. Prosthetic memory: The transformation of American remembrance in the age of mass culture. New York: Columbia University Press.

Liamputtong, P. 2011. Focus group methodology: Principles and practice. London: Sage.

Light, D. 1995. Heritage as informal education. In Heritage, tourism and society, ed. D.T. Herbert, 117-145. London: Mansell.

Light, D. and C. Young 2015. Public Memory, Commemoration and Transitional Justice: Reconfiguring the Past in Public Space. In Post-Communist transitional justice: Lessons from 25 years of experience, eds. L. Stan and N. Nedelsky, 233-251. New York: Cambridge University Press.

McGladdery, C.A., and B.A. Lubbe 2017. Rethinking educational tourism: Proposing a new model and future directions. Tourism Review 72: 319-29.

Mégret, F. 2010. Of Shrines, Memorials and Museums: Using the International Criminal Court's Victim Reparation and Assistance Regime to Promote Transitional Justice, Buffalo Human Rights Law Review 16: 1-56. 
Moore, L.M. 2009. (Re)covering the past, remembering trauma: The politics of commemoration at sites of atrocity. Journal of Public and International Affairs 20: 47-64. Morgan, D.L. 1997. The focus group guidebook. London: Sage.

Nedelsky, N., and L. Stan. 2015. Introduction: Post-communist transitional justice at 25. In Post-communist transitional justice: Lessons from twenty-five years of experience, ed. L. Stan and N. Nedelsky, 1-4. New York: Cambridge University Press.

Petrescu, C. 2017. Nostalgia, identity and self-irony in remembering Romanian communism. In Justice, memory and redress in Romania: New insights, ed. L. Stan and L. Turcescu, 192-213. Newcastle-upon-Tyne: Cambridge Scholars Publishing.

Ploscariu, I.D. 2013. The struggle of Fortinbras and Horatio in Romania: Removal and recollection of the communist past in Romanian museums. Sprawy Narodowościowe 42: 3750.

Pohrib, C. 2016. The afterlives of communist things: Archiving feeling in post-communist Romania. European Journal of Cultural Studies 16: 724-43.

Ramírez-Barat, C., and R. Duthie. 2015. Education and transitional justice: Opportunities and challenges for peacebuilding. New York: International Center for Transitional Justice.

Rusu, M.S. 2017. Transitional politics of memory: Political strategies of managing the past in post-communist Romania. Europe-Asia Studies 69: 1257-79.

Salomon, G. 2004. Does peace education make a difference in the context of an intractable conflict? Peace and Conflict: Journal of Peace Psychology 10: 257-74.

Santayana, G. 1905. The life of reason: The phases of human progress, Vol. 1. New York: Dover Publications.

Simon, R. I. 2006. Museums, civic life, and the educative force of remembrance. Journal of Museum Education 31: 113-21.

Sodaro, A. 2018. Exhibiting atrocity: Memorial museums and the politics of past violence. New Brunswick: Rutgers University Press.

Stan, L. 2013a. Transitional justice in post-communist Romania: The politics of memory. Cambridge: Cambridge University Press.

Stan, L. 2013b. Reckoning with the communist past in Romania: A scorecard. Europe-Asia Studies 65: 127-46.

Stone, M.J., and J.F. Petrick 2013. The educational benefits of travel experiences: A literature review. Journal of Travel Research 52: 731-44.

Tileagă, C. 2012. Communism and the meaning of social memory: Towards a criticalinterpretive approach. Integrative Psychological and Behavioural Science 46: 475-92. 
Todorova, M., and Z. Gille 2010. Post-communist nostalgia. Oxford: Berghahn.

Wight, C. A. 2016. Lithuanian genocide heritage as discursive foundation. Annals of Tourism Research 59: 60-78.

Zembylas, M., and C. McGlynn 2012. Discomforting pedagogies: Emotional tensions, ethical dilemmas and transformative possibilities. British Educational Research Journal 38: 4159.

Zombory, M. 2017. The birth of the memory of communism: Memorial museums in Europe. Nationalities Papers 45: 2018-46.

\footnotetext{
${ }^{1}$ These data were supplied by the Museum
} 